УДК 342.951

DOI https://doi.org/10.32837/pyuv.v2i3(28).354

\author{
B. А. Гвоздій \\ адвокат, \\ аспірант кафедри адміністративного, фінансового і банківського права \\ Інституту права імені князя Володимира Великого \\ Міжрегіональної Академії управління персоналом
}

\title{
РОЗВИТОК ПІДХОДІВ ДО РОЗУМІННЯ АДМІНІСТРАТИВНО-ПРАВОВОГО СТАТУСУ САМОВРЯДНИХ (САМОРЕГУЛІВНИХ) ОРГАНІЗАЦІЙ
}

Питання удосконалення правового статусу самоврядних (саморегулівних) організацій у науці адміністративного права та в актах адміністративного законодавства набувають нині надзвичайної актуальності, оскільки їх ефективне функціонування зумовлює успішність судової реформи, відновлення довіри громадян до правоохоронних та правозахисних органів. Недостатність напрацювань доктринального характеру гальмує розвиток самоврядних (саморегулівних) організацій та не дає змогу повною мірою вирішити наявні у законодавчих та підзаконних актах, а також у правозастосовній практиці проблеми та суперечності. У сукупності ці фактори слугують підтвердженням актуальності теми цієї статті.

Проблематику, пов'язану із визначенням поняття, сутності, змісту та структури правового статусу суб'єктів адміністративного права, розглядали у своїх роботах В.Б. Авер'янов, І.П. Голосніченко, В.К. Колпаков, С.Г. Стеценко та інші автори. Проблеми діяльності самоврядних (саморегулівних) організацій висвітлювали у своїх працях Ю.В. Єльнікова, В.П. Левченко, Є.А. Поліщук, Н.Ю. Філатова, О.С. Яворська та інші науковці. Однак проблеми, пов'язані із визначенням адміністративно-правового статусу самоврегулівних організацій як суб'єктів адміністративного права, ще не здобули достатнього висвітлення в адміністративно-правовій науці.

Мета статті полягала в тому, щоб дослідити розвиток підходів до визначення правового статусу самоврядних (саморегулівних) організацій у науці адміністративного права.

Розглядувана у цій статті проблематика є відносно новою для науки адміністративного права України. Дослідження правового статусу самоврядних організацій у сучасній правовій науці лише розпочинаються, а загальновизнаного визначення поняття вказаних організацій та їх класифікації, на жаль, ще не створено. Однак можна звернутися до міжнародного досвіду у цій сфері, зокрема, до рішення Європейського суду з прав людини, де ще в 1981 році Європейський суд 3 прав людини в справі «ЛеКонт та інші проти Бельгії» констатував, що Орден лікарів Бельгії - це інститут публічного права. Будучи створеним за- конодавцем, а не приватними особами, він інтегрований до державних структур, має мету, в якій втілено суспільний інтерес (у цьому разі охорону здоров'я людей, забезпечуючи відповідно до законодавства деякий публічний контроль за професійною діяльністю лікарів). Для здійснення завдань, які бельгійська держава поставила перед ним, Орден як інститут публічного права користується відповідно до закону дуже широкими правами, в тому числі адміністративними та дисциплінарними, і використовує в зв'язку з цим процедури, властиві публічній владі [1].

Необхідно зазначити, що спроби врегулювати правовий статус саморегулівних організацій почали здійснюватися ще на початку 2000 -х років. У 2009 році до Верховної Ради України було внесено проєкт Закону України «Про саморегулюючі організації» (на нашу думку, вказана назва була невдалою калькою з російського терміна). У пояснювальній записці до вказаного законопроєкту зазначалося, що він спрямований на реалізацію єдиної державної політики щодо захисту інтересів суб'єктів підприємницької діяльності і зниження міри тиску держави на вільні ринкові підприємницькі і професійні стосунки і створення ефективної системи взаємодії держави і бізнесу. Шляхом розвитку "самосвідомості» підприємницьких організацій держава витіснятиметься зі сфери регулювання тих комерційних стосунків, присутність в яких державного елементу видається зайвою $\mathrm{i}$ невиправданою 3 точки зору основних функцій державного регулювання. Термін «саморегулювання» в буквальному розумінні означає добровільне накладення на себе яких-небудь обмежень. У застосуванні до економічної діяльності це поняття розвивається і розуміється як регулювання діяльності у визначеному секторі ринку без втручання держави. Держава встановлює загальні рамки діяльності суб'єктів певного сектору ринку, спрямовані на захист інтересів суспільства. Норми саморегулювання розвивають і доповнюють норми державного регулювання [2].

Вказаний законопроєкт викликав критику Головного науково-експертного управління Верховної Ради України, яке у своєму висновку звернуло увагу на те, що проєкт дублює Модельний 
закон про саморегульовані організації, прийнятий на двадцять дев'ятому пленарному засіданні Міжпарламентської Асамблеї держав-членів СНД (Постанова № 29-7 від 31 жовтня 2007 року). 3 цього приводу Головне науково-експертне управління Верховної Ради України зауважило, що модельні закони, яким властивий методологічний характер, розробляються 3 метою допомоги державам у регулюванні відповідних суспільних відносин 3 урахуванням особливостей національної правової системи. Проте аналіз положень внесеного проєкту дає підстави дійти висновку, що вказаний Модельний закон відтворений у положеннях проєкту без жодних змін та адаптації до наявної в Україні системи нормативно-правових актів, що регулює суспільні відносини, які склалися в нашій державі. Крім того, зазначалося, що складається враження, що продубльований текст Модельного закону не був належним чином граматично та стилістично відредагований, а лише механічно і не завжди вдало перекладений з російської мови. Іноді в ньому застосовуються терміни, зміст яких невідомий українському законодавству. Наприклад, згідно з частиною 2 ст. 12 проєкту саморегулюючій організації заборонено «фундирувати» господарські товариства. У п. 1 частини 3 цієї статті передбачено, що особа, яка здійснює функції одноособового «виконавського» органу, не має права набувати «коштовних паперів», емітентами яких або боржниками по яких є члени саморегулюючої організації. Згідно з п. 1 ст. 7 проєкту саморегулююча організація зобов'язана розкривати за допомогою «вистави в електронно-цифровій формі... інформації». У п. 5 частини 5 ст. 8 проєкту саморегулюючій організації надається право звертатися до відповідних державних органів 3 клопотанням про подання до суду заяви про дискваліфікацію своїх членів. У ст. 11 та 12 застосовується термін «компанії, що управляють». Вказане, на думку Головного науково-експертного управління Верховної Ради України, значною мірою ускладнює роботу над законопроєктом, адже здебільшого проблематично встановити справжній зміст запропонованих норм. До того ж у теоретичному відношенні викликав сумнів термін "саморегулююча організація», який запозичений із законодавства РФ і який без достатніх підстав використовується у проєкті. Справа у тому, що словосполучення "саморегулююча організація» генетично походить від терміна «саморегулювання», яке поряд із самоорганізацією, самоконтролем є одним 3 проявів процесу самоврядування (самоуправління, саморегулювання), що здійснюється у добровільних громадських організаціях. Тому Головне науково-експертне управління Верховної Ради України вважало, що у проєкті слід використати термін «самоврядна організація» [3]. Ми повністю погоджуємося з цього приводу з дум- кою експертів, справді, за наявності у науковому обігу власних українських термінів дивно було б штучно створювати кальку з іншої мови, яка до того ж викривлено подає сутність досліджуваних організацій (що зумовлене як відмінностями у законодавстві, так і різноспрямованістю розуміння ролі недержавного сектору в українській та російській державно-правовій доктрині).

У цей це період до Верховної Ради України було подано проєкт Закону про фахові саморегулівні і самоврядні об'єднання (як можна побачити, вказана назва подавала як автономні обидва терміни, що не могло ще більше не заплутати правокористувача) [4].

Вказаний законопроєкт також викликав низку зауважень Головного науково-експертного управління Верховної Ради України. Зокрема, зазначалося, що у ст. 1 законопроєкту пропонується закріпити, що «фахове об'єднання» - це «вид громадського об'єднання, що створюється шляхом самоорганізації фізичних та/або юридичних осіб 3 метою реалізації суспільних інтересів, впровадження засад саморегулювання та/або професійного самоврядування у визначеній професії, сфері діяльності чи галузі відповідно до статуту об'єднання». Запропоноване визначення не повною мірою узгоджується з конституційними приписами, зокрема з положенням ч. 1 ст. 36 Конституції України, відповідно до якої громадяни України мають право на свободу об'єднання у політичні партії та громадські організації для здійснення i захисту своїх прав і свобод та задоволення політичних, економічних, соціальних, культурних та інших інтересів, за винятком обмежень, встановлених законом в інтересах національної безпеки та громадського порядку, охорони здоров'я населення або захисту прав і свобод інших людей. Отже, якщо у цьому разі під фаховими об'єднаннями мається на увазі форма реалізації громадянами України права на свободу об'єднань, то варто зважити на те, що згідно 3 конституційними приписами об'єднання громадян можуть існувати у двох видах: політична партія та громадська організація. Крім того, не зовсім вдалим є використаний у визначенні змісту поняття «фахове об’єднання" термін "суспільні інтереси», який несе інше смислове навантаження: громадські, спільні, а не визначає напрями (сфери) суспільних відносин, у яких можуть бути реалізовані інтереси громадян. I, як і в іншому законопроєкті, про який ми писали вище, у теоретичному відношенні викликав сумнів термін «саморегулююча організація», запозичений із законодавства РФ [5].

Але на цьому розвиток законотворчості не зупинився. Протягом 2010-2011 років до Верховної Ради України було подано проєкт Закон України "Про саморегулювальні організації», назва, а отже, основоположне поняття, предмет правового 
регулювання ніяк не узгоджувалися ні з правилами українського правопису, ні з національним законодавством. Заслуговує на увагу думка Головного науково-експертного управління Верховної Ради України, яке насамперед звернуло увагу на те, що саморегулювальні організації, діяльність яких пропонується регулювати, є (разом із благодійними, громадськими та деякими іншими відповідними організаціями) окремим видом непідприємницької (неприбуткової) організації. У зв'язку з цим, на думку експертів, з точки зору оптимального забезпечення комплексного регулювання відповідних суспільних відносин більш доцільним стало б прийняття загального закону про такі організації, а не законів про кожний вид непідприємницької (неприбуткової) організації, зокрема, про саморегулювальні організації, як це пропонується суб'єктами цієї законодавчої ініціативи. Це пояснюється тим, що прийняття спеціального закону про кожний вид такої організації не лише невиправдано збільшує кількість законодавчих актів, але й ускладнює правозастосування, оскільки для окремого виду організації встановлюються умови створення та діяльності, відмінні від умов створення та діяльності іншої подібної організації, замість їх розумної уніфікації [6].

Не викликає подиву, що постановою Верховної Ради України від 23 вересня 2010 року № 2570-VI вказані законопроєкти було повернуто на доопрацювання, а згодом знято з розгляду. Разом із тим, як справедливо зазначає I.M. Гармаш, основною ідеєю появи таких законопроєктів стало запровадження загальносвітових тенденцій із децентралізації влади за допомогою формування та функціонування різних механізмів регулювання діяльності представників певного професійного середовища [7, с. 62].

Новий поштовх проблема правового статусу самоврядних організацій отримала під час реалізації судової реформи. Закріплення у законодавстві правових засад діяльності низки самоврядних організацій, з одного боку, сприяло підвищенню ефективності діяльності судової та правоохоронної системи, але з іншого-внаслідок прогалин та суперечностей у законодавстві сприяло появі великої кількості судових позовів у досліджуваній сфері.

Проблема визначення та вдосконалення правового статусу самоврядних (саморегулівних) організацій, безумовно, потребує прийняття законодавчого акта, яким поняття, ознаки, форми вказаних організацій було б визначено з опорою не на досвід Співдружності Незалежних Держав, як у попередніх проєктах, а на досвід держав Європейського Союзу. На нашу думку, поняття самоврядної організацій можна визначити: як інститут публічного права, створений на підставі закону, який виконує низку суспільно значущих функцій, пов'язаних з реалізацією публічного ін- тересу, у певній професійній сфері. Відповідно, завданням науки адміністративного права має стати перш за все обгрунтування належності відносин, які виникають у сфері діяльності самоврядних (саморегулівних) організацій, до предмета адміністративного права.

Перспективи подальших наукових розвідок мають включати визначення ознак самоврядних організацій, їх функцій, форм діяльності та особливостей гарантій їх функціонування у системі публічної влади.

\section{Jimepamypa}

1. Ле Конт, Ван Левен и Де Мейер против Бельгии. Практика Європейського суду з прав людини. URL: https://precedent.in.ua/2015/12/16/le-kont-van-leveny-de-mejer-protyv-bel/ (дата звернення: 11.08.2019р.).

2. Пояснювальна записка до проєкту Закону України «Про саморегулюючі організації. URL: http://w1.c1.rada.gov.ua/pls/zweb2/webproc4_2? pf $3516=4841 \& \mathrm{skl}=7$ (дата звернення: 11.08.2019 р.).

3. Висновок на проєкт Закону України «Про саморегулюючі організації (реєстр. № 4841 від 16.07.2009 р., внесений народними депутатами України А.К. Кінахом, М.В. Чечетовим, В.В. Януковичем, В.М. Гуреєєвим, M.C. Комаром). URL: http://w1.c1.rada.gov.ua/ pls $/$ zweb2/webproc4_2?pf3516=4841\&skl=7 (дата звернення: 11.08 .2019 р.).

4. Пояснювальна записка до проєкту Закону про фахові саморегулівні і самоврядні об'єднання. URL: http://w1.c1.rada.gov.ua/pls/zweb2/webproc4 2 ?pf $3516=4841-1 \& \mathrm{skl}=7$

5. Висновок на проєкт Закону України «Про фахові саморегулівні і самоврядні об'єднання" (реєстр. № 4841-1 від 10.09.2009 р., внесений народними депутатами України К.М. Ляпіною, В.Г. Карпуком, B.B. Мойсиком та A.B. Шевченком). URL: http://w1.c1.rada.gov.ua/pls/zweb2/webproc4_2? pf3516=4841-1\&skl=7 (дата звернення: $11.08 .2019 \overline{\mathrm{p}}$.).

6. Висновок на проєкт Закону України «Про саморегулювальні організації" (реєстр. № 4841-д від 17.12.2010 року, внесений народними депутатами України Н.Ю. Королевською, С.В. Власенком, А.К. Кінахом, К.М. Ляпіною, М.В. Чечетовим). URL: http://w1.c1.rada.gov.ua/pls/zweb2/webproc4 2 ?pf3516=4841-\% D0\% B4\&skl=7 (дата звернення: 11.08.2019 p.).

7. Гармаш I.M. Основні етапи розвитку саморегулівної галузі на території сучасної України. Право та інновацї̈. 2015. № 2 (10). С. 60-65.

\section{Анотація}

Гвоздій В. А. Розвиток підходів до розуміння адміністративно-правового статусу самоврядних (саморегулівних) організацій. - Стаття.

У статті міститься аналіз наукових підходів до дослідження правового статусу самоврядних (саморегулівних) організацій. Автор досліджує особливості доктрини адміністративного права. Особлива увага присвячена аналізу законопроєктів у досліджуваній сфері та зауваженням до них.

Мета статті полягала в тому, щоб визначити особливості наукових підходів до вивчення проблематики функціонування самоврядних (саморегулівних) організацій у науці адміністративного права.

Автор звертає увагу на те, що дослідження правового статусу самоврядних організацій у сучасній юридичній науці тільки починаються. Загальноприйняте 
визначення поняття цих організацій і їх класифікації ще не створено, що зумовлює необхідність здійснення активних наукових пошуків.

У статті аналізується досліджувана концепція в міжнародній та вітчизняній практиці. Автор обгрунтовує, що проблема визначення і вдосконалення правового статусу самоврядних (саморегулівних) організацій вимагає прийняття спеціального законодавчого акта.

Автор визначае поняття «самоврядна організація»: як інститут публічного права, створений на основі закону, який виконує низку соціально значущих функцій, пов'язаних з реалізацією громадських інтересів в тій чи іншій професійній сфері. У статті акцентується увага на відмінностях між поняттями «самоврядна організація» $\mathrm{i}$ «саморегулівна організація».

Завданням науки адміністративного права має бути перш за все обгрунтування приналежності відносин, що виникаютьусферідіяльностісамоврядних(саморегулівних) організацій, до суб'єкта адміністративного права.

Автор обгрунтовує, що подальші наукові дослідження мають охоплювати визначення характеристик самоврядних організацій, їх функцій, форм діяльності і особливостей гарантій їх функціонування в системі публічної влади. Стаття закінчується визначенням подальших перспектив для розгляду цього питання.

Ключові слова: адміністративне право, публічний інститут, суспільний інтерес, самоврядна організація, саморегульована організація, правове регулювання.

\section{Summary}

Gvozdiy $V$. A. Development of approaches to understanding the legal status of self-governing (self-regulatory) organizations. - Article.

The article contains an analysis of scientific approaches to the study of the legal status of self-governing (self-regulatory) organizations. The author explores the features of the doctrine of administrative law. Particu- lar attention is devoted to the analysis of bills in the field under study.

The purpose of the article was to determine the features of scientific approaches to studying the problems of the functioning of self-governing (self-regulatory) organizations in the science of administrative law.

The author draws attention to the fact that the study of the legal status of self-governing organizations in modern legal science is just beginning. A generally accepted definition of the concept of these organizations and their classification has not yet been created.

The article analyzes the studied concept in international and domestic practice. The author substantiates that the problem of determining and improving the legal status of self-governing (self-regulatory) organizations requires the adoption of a special legislative act.

The author defines the concept of a self-governing organization as a public law institution created on the basis of a law that performs a number of socially significant functions related to the realization of public interests in a particular professional field.

The author focuses on the differences between the concepts of a self-governing organization and a self-regulatory organization.

The task of the science of administrative law should be first of all the justification of the ownership of relations arising in the field of activity of self-governing (self-regulatory) organizations in the subject of administrative law.

The author substantiates that further scientific research should cover the definitions of the characteristics of self-governing organizations, their functions, forms of activity and features of guarantees of their functioning in the public authority system. The article ends with a definition of further prospects for addressing this issue.

Key words: administrative law, public institution, public interest, self-governing organization, self-regulatory organization, legal regulation. 